\title{
The Influence and Legacy of the Shepherding Movement on the Current Neo-Pentecostal Movement in South Africa
}

\author{
Kelebogile T. Resane \\ resanekt@ufs.ac.za
}

\begin{abstract}
This essay focuses on the history, theology, and demise of the Shepherding movement, a discipleship network pioneered by five teachers, Charles Simpson, Bob Mumford, Derek Prince, Don Basham, and Ern Baxter, based in Fort Lauderdale, Florida, USA. These leaders aimed to provide meaning and order through house churches and cell groups to address the spiritual maturity of the Charismatic believers. Some key concepts of the Shepherding movement that impacted the Neo-Pentecostals will be discussed, namely submissions to authority; male leadership; ecclesiology; pastoral training and formation; and church polity, emphasizing the apostolic and prophetic ministries. The second part of the essay highlights the current Neo-Pentecostal movement and how it has taken over the legacy of extra-biblical revelation from the Shepherding movement. This reveals the influence that the Shepherding movement has left, after it has been inherited by the Neo-Pentecostal movement.
\end{abstract}

Keywords: Shepherding movement, shepherd, Charismatic, Neo-Pentecostal, submission, authority

\section{Introduction}

Broadly speaking, the term 'Charismatic' within the Christian context refers to that branch of Christianity that expresses its spirituality and worship by emphasizing charismata - spiritual gifts, operational in believers' lives - 
individually or corporately. Historically, Charismatics evolved out of Protestant and Catholic traditions in the 1960s. It is not recreant to call this Christian phenomenon 'Pentecostals within mainline Christianity' (Barker 2001: 105). It was never their intention to secede into a denominational formation, but in the middle of the 1970s and early 1980s, theological thoughts led to new ideas of breaking out of the shell.

When the Charismatic movement (Renewal) started to realize that the new wine cannot be put into the old skins, the sentiment of withdrawal from the established mainline churches loomed, and one of the offshoots was the Shepherding movement that was sometimes called Discipleship movement. At some stage it was also called the Christian Growth movement. In those days, they were found among all the traditional or mainline denominations and were generally viewed as the Spirit's work across the denominations including the Catholic Church.

Charismatics were informally connected as independents, therefore needing some form of formal organization to facilitate their discipleship processes towards Christian maturity. The term 'movement' became popular in contrast to 'denomination', as Charismatics of the time were anti-institutional and abhorrent of any thought of denominalization. The emergence of the movement was due to shallow commitment, community, and the prevailing worldliness in North American churches during the seventies and the eighties. They were seeking for some new ways of doing church. There was a gap for some dynamic discipleships and networks to respond to the dynamics of the time. These leaders aimed to provide meaning and order for their movement through home fellowships or cell groups. They were also concerned about the spiritual development and growth of the believers. This is asserted by Moriarty (1992:76) that as an independent force, the movement 'arose out of a deep concern for effective discipleship and spiritual maturity'.

This shows that the movement did not emerge as a result of any theological deviations within Pentecostal or Charismatic circles. Their concerns were lenient towards ecclesiology as they put their main emphasis on spiritual maturity and discipleship. In other words, praxis, not dogma was their concern. 


\section{Historical Overview}

The Shepherding movement was 'born in 1974 after two Shepherds conferences gave a higher profile to the teachings on submission and authority' (Hayford \& Moore 2006:242). It started as a weekly Bible study in Fort Lauderdale, where five Charismatic Bible teachers met. They were sometimes called the Fort Lauderdale Five. It was an interdenominational ministry that exerted its influence through teaching conferences concentrated in Florida, and later expanded nationally and internationally, especially in the United Kingdom and Australia. The movement gained momentum in the 1970s and the 1980s. One of the leaders was Don Bashan, whose gentle character and teaching methodology are explained by Moore as 'clear, strong, and laced with stories and humour' (Moore 2003:35). Resane (2008:52) indicates that Bashan's ministry focus was freedom from demonic oppresssions, and the baptism in the Holy Spirit.

Then there was Ern Baxter, who settled in Fort Lauderdale in 1975. He was older than the others and 'the most experienced seasoned preacher' in the Shepherding movement (Resane 2008:53). Moore (2003:37) points out that Baxter participated directly or indirectly in three waves of Pentecostal revivals.

Third was Bob Mumford who, together with his family, took residence in Fort Lauderdale in 1970 and started building his family, ending up with four children. According to Resane (2008:53), Mumford was the movement's spokesperson and the frontal image. Then there was Derek Prince who excelled academically, mastering Hebrew, Latin, and Greek. During his military assignment due to World War Two in Jerusalem, he met and married Lydia Christianson. She died in 1975. They did not have their own biological children but adopted eight girls from different racial groups. He became a missionary in Kenya as part of the Pentecostal Assemblies of Canada. In 1968, he settled in Fort Lauderdale where he remarried in 1978. His second wife's name was Ruth. His teaching focused on overcoming demonic powers, intercessory prayer, and glossolalia from a classical Pentecostal view of this gift as an evidence of Spirit baptism (Resane 2008:54). Fifth was Charles Simpson who was introduced to the Charismatic renewal in 1964 by his friend, Ken Sumrall, focusing on Spirit baptism (Moore 2003:41). Under the Charismatic convictions, he became an itinerant preacher, operating from Fort Lauderdale. Resane (2008:53) highlights the 
fact that Simpson directed and influenced the Shepherding movement 'more than any of the other teachers'.

The movement's mouthpiece was the New Wine magazine, established in 1969. In 1972 it changed its name to Christian Growth movement. According to Barret (1982:429), around 100,000 people were associated with it. The Shepherding movement's magazine, New Wine, distributed thousands of copies in 1976 in over 140 nations. More than half of its readership was made up of church leaders. In addition, a wider distribution and promotion of the movement's teachings were made through the five teachers' personal newsletters, tapes, and books. Barret (1982:430) points out that statistically the distribution of magazines, newsletters, cassette tapes, and books flourished. These are the only sources available to formulate research conclusions about the Shepherding movement (Barret 1982:431).

\section{Theology and Methodology}

First, the focus of the movement's theology was on submission to authority. As far as they were concerned, the greatest spiritual protection was guaranteed by submission to spiritual authority. As confirmed by Moore (2003:42), these leaders believed that submission and protection were intertwined as they provided the necessary success and stability for those in Christian leadership. This is also confirmed by Simpson (1972:24-27) that submission to God's delegated authority is necessary in all spheres of life. In the same vein, Mumford (quoted in Moore 2003:55-56) unequivocally declares that where there is a group of people with a mutual commitment to each other, they need to find a shepherd for their soul's sake.

Mumford and Simpson opine that the key to pastoral leadership is a definite personal relationship between a person and a shepherd leader. A closer scrutiny to this notion leads to the conclusion that the movement promoted what Young (2019) calls, a 'pyramid scheme for discipleship', through which a 'Christian submitted himself [sic.] to a shepherd, who took on responsibility for his [sic.] whole-life discipleship'.

These teachers insisted that church involvement entails a balanced relationship between a senior shepherd and fellow believers. Moore (2003: 75) highlights that involvement goes along with commitment to a shepherd. This leads to the conclusion that discipleship and authority are intertwined. 
This inter-relatedness is a covenant relationship which acts as a solution to the problem of autonomy or 'stand-alone' attitude among Charismatics. The connection between shepherds and fellow Christians is demonstrated through commitment and loyalty, accountability, and service within and for the community.

For these leaders, submission involved the sharing of one's life, including decisions on any changes that may affect one's life direction. For instance, Mumford (1975b:5) reiterates that 'submission means that we intend to share our lives and decisions as openly as possible'. This means that there should be consultations with the shepherd for any decisions or directions of life intended by the follower. These decisions and directions include inter alia career guidance, job changes, financial undertakings, time management, and marriage guidance.

This led to the followers being kept ransom by the authority of their leaders. Decisions on petty issues were to be consulted with shepherds. This is demonstrated by Mumford's insistence that shepherds were to take full leadership of every 'sheep's' personal life including behavioral practices such as etiquette, dress code, financial control, and home life (Mumford 1975a:5). Inevitably, Mumford alludes that heretic or dissenting voices should be silenced through an emphasis on authority, submission, and servanthood. $\mathrm{He}$ agrees with Young (2019) that the followers were expected to pay blind allegiance to the leaders, since they received from these leaders some loving and caring pastoral care.

This was overridden by a strong emphasis on pastoral care, and the freedom of conscience that characterized the innate reality of the movement's modus operandi. The exercise of authority was organizationally hierarchical, while operationally it was pyramidal.

The second tenet in the theology of the Shepherding movement is the male leadership. There was an emphasis on male leadership where men had to be home leaders and good husbands. Men were fiercely criticized for abdicating and abandoning their roles as heads, both in religious and secular spheres. Women were not allowed to take positions in church government (Basham 1974:16). In all their literature and audio sources, shepherds only were referred to as men. Women were not mentioned as shepherds. They were expected to be submissive to their husbands. They claimed that healthy families, led by spiritual men, make a healthy church (Moore 2003:79). The hierarchy proposed by the movement's leaders was that spiritual leadership is 
based on submission to spiritual authority (Basham 1974:15). This mutual submission, based on the husband-wife relationship submission modeled what all leaders needed.

The third concept is that of ecclesiology. As far as the Shepherding movement was concerned, the church was both invisible and universal (Mumford (1975b:4). The local church was both the community and the movement of the people of God, and not an architectural design or an institutionalized entity. Durnbaugh (1964:33) argues that these teachers interpreted the church as a disciplined community living a life of relationship with Jesus. Furthermore, they considered their ecclesiology to be theocentric while at the same time geared to the times, not stuck in the old mold or traditions (Moore 2003:68). Their priority continued to be the building of the local churches that visibly manifests the kingdom of God (Moore 2003:72). The movement insisted that the church should create an alternative society that would impact and influence communities positively (Mumford 1976:11). The church as the redeemed community was to be the vehicle of evangelism. However, one observes that the movement did not give much priority to evangelism.

In his book, Christ in Session, Mumford (1973:82-83) claims that believers should be active participants, not just spectators. They were to be vital participants in the church. As participants in covenantal relationships, they had to reject the prevailing spirit of independence, as it was deemed that walking alone was not consonant with the biblical communion of believers (Moore 2003:57).

In agreement with Simpson (1972:26), Basham (1980:33) describes the Shepherding movement as a covenant community of 'God's redeemed people', living together in love under God-appointed leaders who lead with love and exhibit a life of integrity, fidelity, and respect for women and children.

This was further enhanced by a belief that this community had to be a place of loving disciplinary and corrective instruction towards healthy personal growth. The church as a cohesive community has an opportunity for excellent dedication of one's talents and gifts for the empowerment of other members. In agreement with broad evangelical ecclesiology, Mumford (1980: 33) drives the point home that the church should be a community of believers exhibiting the fruit of the Holy Spirit by worshipping, praising, and serving God selflessly as individuals and corporately. It is the community that is 
Christo-pneumatic in essence, as it derives its inspiration and direction from Christ and the Spirit.

This description encapsulates ecclesiology, based on and characterized by togetherness (covenant community), character (holiness, fidelity, etc.), family life, submission to authority, expressive worship, and a Christo-pneumatological centrality in a missional exertion in the world. This ecclesiastical definition puts emphasis on the church as the visible community of believers, living a distinct life from that of the world (Moore 2003:152). It is therefore justifiably correct to conclude that 'the Shepherding movement emphasized the relational organic nature of the church' (Young 2019). For them, the covenant community should demonstrate life within the operation of spiritual gifts that is accompanied by a reputable personal character. Basham (1986:189-190) adds and stipulates that interpersonal ministerial conflicts 'should be handled according to the Matthew 18 guidelines'.

There are also issues regarding pastoral training and formation. Unlike the usual Pentecostal reservation regarding academic pursuance, the five founding leaders of the Shepherding movement were academically astute. For instance, Simpson, a Baptist turned Charismatic, obtained his junior degree from William Carey College and furthered his theological studies at New Orleans Baptist Theological Seminary. This helped him to 'become the movement's structural architect' (Moore 2003:150). Prince studied the ancient languages Greek, Latin, Hebrew, and Aramaic at three universities (Eton College, Cambridge, and Jerusalem). He was a visiting lecturer in Ancient and Modern Philosophy at King's College. Baxter never attended high school fulltime, but was an ardent reader, and became an itinerant international preacher. He was an eloquent orator par excellence. After completing his high school education in the Navy, Mumford graduated with a Bachelor of Science in Bible from Valley Forge Christian College. He attended the University of Delaware and then received his Master of Divinity degree from the Reformed Episcopal Seminary in Philadelphia. Basham trained as a commercial artist, and in 1951, he entered the ministry, studying at the Phillips University Seminary. He was ordained in ministry by the Disciples of Christ in 1955, and pastored churches in North America.

Regardless of these teachers' academic embrace, there was a subliminal sentiment that seminary education is not important. Instead, there was a promotion of a mentoring model for ministry training. This sad 
scenario was captured by Prince at the Leesburg Shepherds Conference of 1973 when he discouraged seminary qualifications but promoted the mentoring model for ministerial formation and training (Moore 2003:63). Theological education for ministerial assignments was therefore never a priority or emphasis for the Shepherding movement's leaders. The conferences, literature, and audio cassettes served as resources for equipping church leaders. The bottom line is highlighted by Young (2019), that the Shepherding movement emphasized informal and unorthodox leadership training requirements.

There was also an issue of church polity. Young (2019) highlights that the movement did not prioritize church polity as a tool or means of dealing with church conflicts. Church polity for the movement entailed that the authority in the local church rests and ends with elders for the administration of local church affairs, while the apostolic ministry rests and operates through the invitation from the local presbytery of elders. This is particularly emphasized by Prince who advocated for today's ministries under the leadership and directions of the apostles and prophets (Prince 1972:19; 1973:12; cf. Moore 2003:63). The teachers taught frequently on the fivefold ministry referred to in Ephesians 4:11-12.

Prince (1972:19) promotes the ecclesiological polity of 'one city, one church' where Christians convene and converge regularly across the denominations in small gatherings or cells, with another purpose of creating a platform for emergence of leaders for the city. This was idealistic and not practical, and the idea never took off the ground. It is a pyramid church structure with the congregation at the base, followed by house-group leaders, elders, pastors, and the apostles at the top (Moriarty 1992:76).

Undoubtedly, this pyramidal structure established order and encouraged maturity through discipline. The exertion of submission to authority was therefore escalated. Unfortunately, due to its dictatorial or dubious canonical justification, it opened a wide door for 'misuse of authority, false teaching, domination, elitism, pride, and other abuses' (Moriarty 1992:77), as followers were pressurized to conform without questioning, while they had to tolerate the emotional and spiritual oppression, due to the demanded submission to the shepherd. 


\section{The Neo-Pentecostal Movement: Extension of the Shepherding Movement}

The Neo-Charismatic movement is sometimes referred to as 'Third Wave [churches that] emerged in the 1970s, and was identified by large, loosely affiliated, independent (or non-denominational) churches' (MacTavish 2014: 2). Some scholars refer to this movement as the Neo-Pentecostal movement or (more recently) the New Apostolic Reformation. No matter how one labels it, it remains an Evangelical Pentecostal Protestant movement, composed of independent churches and organizations that focus on the operation of charismata. Their distinctive praxis includes casting out demons, healing the sick, and believing in being filled with the Spirit (Hayford \& Moore 2006:278). It also includes deliverance and prophetic revelations, which are always personal and extra-biblical, meaning that these prophecies are not always about God's written word, but based on the person being prophesied or the one who prophesies. Not much is about what the Bible says in relation to these metanarratives. The movement has its roots in the classical Pentecostalism, Renewal movement, and the mainline Christianity. The movement is transdenominational, theologically diverse, and ecumenical through its network systems. The terms 'Neo-Charismatic' and 'Neo-Pentecostal' are therefore used interchangeably to refer to the same renewal movement.

The phenomenal growth of the movement was supported in South Africa, when this country became more susceptible to African religions after 1994. South Africa became a territory of hope, while the citizenry's religious naivety was scrutinized by 'religious leaders' from other parts of the continent, especially Nigeria, Ghana, and the Democratic Republic of Congo. These leaders brought with them the Charismatic notion of personality cult. Surfing through the internet, one occasionally comes across Mumford (one of the leaders or teachers in the Shepherding movement), considered to be a spiritual 'Papa' to thousands of Christians worldwide who claim the influence of Mumford towards their spiritual growth and service in the kingdom of God. This 'Papa' or 'Mama' cult is impressed through a commanded demand on the devotees to submit to the authority under the man or woman (cf. below) of God. The titles or names assigned to these preachers, either by themselves or their followers include the likes of 'Papa' and 'Mama', 'Major One', 'Man of God' or 'Woman of God', and 'Anointed'. The 'shepherd' entitlement from the Shepherding movement has made some indelible marks 
on the current South African Neo-Pentecostalism. According to Gunda and Machingura (2013:17), these leaders distinctively hold these titles through self-propagation or through the followers' propagation and bestowal on them.

As mentioned above, the teachers of the Shepherding movement taught the fivefold ministry of Ephesians 4:11-12. The rationale behind this is that they deemed traditional church polity as irrelevant and that it should be abolished and replaced with the fivefold ministry (Resane \& Buitendag (2008:1528). The teaching of this notion led to a conclusive ecclesiastical polity and understanding of the current Neo-Pentecostal movement. Since the evolution of the Shepherding movement, the fivefold ministry titles were applied. The Neo-Charismatics became and still are obsessed with these five titles. This title obsession was enhanced by the rising of the New Apostolic Reformation founded in the USA in the eighties, with the emphasis on Ephesians 4:11-12. This caused the elevation of specific ministry titles such as 'Apostle' and 'Prophet'. According to Mzondi (2017:101), a 'plethora of names like "apostles", "prophets", "pastors", "evangelists", "bishops", "archbishops", "Dr" or a permutation of "Dr" and "apostle" or "prophet", surfaced amongst these leaders'.

\section{The Negative Side of the Shepherding Movement}

The five Shepherding movement teachers did not see themselves as apostles, but their followers deemed them as such (Moore 2003:85). They regarded themselves as pastors (shepherds). The issue of submission to authority ended, labeling the movement as cultic, as it opened many doors for the abuse of power. Here in South Africa, the movement has left footprints of the commercialization of the gospel whereby devotees are promised blessings in proportion to the amount of money given to the 'Papa' or 'Man of God'. As observed in some current cases presented at the Commission for Religious and Linguistic Rights, human trafficking and women abuses are all undertaken by declarations of submission under the authority of the pastor.

From their evangelical heritage, the Shepherding movement emphasized male leadership and female co-leadership. The five co-founders were white males, and in their networks, there was a limited woman participation. According to Quebedeaux (1983), Prince emphasized Christian growth and behavioral change through the teachings of God-commissioned elders 
(shepherds) - always male. It is only in the recent past that the NeoCharismatic movement has opened itself to female leadership. Currently, there are many Charismatic churches led by women and they are doing well.

The ecclesiology of Neo-Pentecostal movements is proliferated, as the doctrine of the church is muddled up with the practices of the corporate world. It was already mentioned above how the covenant community was involved in human details by usurping the personal responsibilities of the members. The shepherd was to act as lord over the disciples, in order to interfere and intervene in their personal matters. This opened the door of exerting control on people's lives, including their wealth, time, and integrity. The church became an instrument of commercial gains. Today's Neo-Pentecostal preachers, disguised as prophets, indulge in people's personal and private affairs. The socalled miracles are orchestrated in such a way that people's rights are abused and their dignity denigrated. The pursuit to get big numbers of congregants on Sundays has the underlying motive of financial gain. It is not anymore about evangelism and discipleship.

The pyramid system of discipleship through the cell church vied by the Shepherding movement, engrossed and enhanced relationships. The stress on the covenant community enlarged the people's sense of belonging - the need for modern humanity who is living in isolation, navel-gazing all the time. The Neo-Charismatics of the time have become a celebrity cult where attention is paid to the preacher, and to nobody else. Performance has become the order of the day and pastoral success is measured by the financial accumulation and collection on a weekly basis. The pulpit has become the platform for egoistic elevation. This is a departure from Christ's missional mandate of evangelizing and discipling the world towards Christlikeness. One of the New Apostolic Reformation teachers, David Cannistraci has tried to caution this tendency by declaring that the "[a]postles never saw themselves as men who controlled the lives of those submitted to them, but respected man's freewill and chose cooperation instead of control' (Cannistraci 1996:149). The current appearances at the Commission for Religious and Linguistic Rights, and AmaBishopo programme on MojaLove television (channel 157), conscientize South Africans that many followers of the Neo-Charismatic leaders are open and subjected to spiritual abuse. Johnson and VanVonderen (1991:20) define spiritual abuse as 'the mistreatment of a person who is in need of help, support or greater spiritual empowerment' with the intended aim of demeaning that person's potentials to grow. 
These ecclesiastical manifestations or practices are not canonically justified, textually correct, or hermeneutically appropriated. The tendencies to abuse the seekers of truth are appalling, therefore shameful and disrespectful to human dignity (seeker) and integrity (leader) e.g., making people to eat grass, shaving women's private parts, and spraying people with insecticides. These practices demonstrate what Johnson and VanVonderen (1991:21) refer to as abusive power for bolstering the leader's ego for dominance over those who consult him for their needs to be met. When a seeker or a devotee needs assistance or some form of divine intervention in a personal crisis, it is expected that whatever diagnosis is prescribed by the shepherd, there should be unquestioned compliance. The abuse encapsulates the overriding of feelings and opinions of another, disregarding the emotional trauma that the seeker might consequently go through. The unquestioned and misused authority comes to the fore when those without power are getting hurt. To this effect, Kraft cautions that when authority is misused or abused, 'God is angered when those with authority use it to hurt the powerless' (Kraft 1997:96). The misused authority is fatal to human existence, security, and safety. It strips humans who are the imago Dei of their dignity, respect, and integrity.

Secularization alluded to by Prince (1973:12) when he promoted 'one city, one church' in a geographical area is welcomed by the modern NeoCharismatic churches in South Africa. People gather in big numbers as they aim to take over other existing churches in the community. The rendezvous for their gatherings in huge spaces such as stadia and showgrounds attest to this 'one city, one church' principle. Soul-winning is replaced by sheep-swopping, which is the migration of church members from their original churches to the new churches led by these Charismatic leaders. Neo-Charismatic ecclesiastical expressions are hardly traced in the poor areas such as villages, informal settlements, or under-developed townships. These areas are not contextually correct as far as the Neo-Charismatic ecclesiology is concerned, as preaching wealth and health there would sound like an oxymoron. These places are not economically viable, and therefore cannot be blood-sucked for 'church' prosperity viability. The residents in these areas are poor and are living in unhygienic squalid conditions with inadequate health facilities. The Church Fathers' dictum of the church as the center of kerygma and the administrative point for sacraments (Belgic Confession, Art. 29) critiques the prosperity gospel's missional advancements away from the poverty-stricken 
areas. One cannot just kerygmatically call upon the poor person to be wealthy, without being diaconally involved.

The Neo-Pentecostals are missing the reality that the church as a dignified institution, bought by the blood of Christ and sanctified by the Holy Spirit, is tarnished when used as a vehicle of human abuse. This abuse comes in different cloaks such as deceptively collecting monies from people, invading people's privacy and dignity by forcing them into strange practices such as asking them to strip naked or touching their genitalia publicly, eating grass or snakes, drinking petrol, and spraying them with insecticides. These practices, though not common within the erstwhile Shepherding movement, are encouraged by the movement's failure to address the unaccountable 'independence' attitudes within the renewal movements of the time.

These practices are exacerbated by their reservation regarding academic theological reasoning. As pointed out above, although four of the five Shepherding teachers were academically equipped, they took a low esteem towards theological education. Quebedeaux (1983:98) highlights that an ascendancy to leadership disregards formal trainings or processes of ministerial formations or probations. Leadership conferences, popular literature (their books, New Wine magazines, and audio cassettes) were regarded as reliable tools or platforms for ministerial training. Many of the NeoPentecostal preachers in South Africa are not theologically trained. If indeed, it is through some short or online courses that offer a little content for basic Bible studies. Some of their colleges with physical structures offer qualifications that are not accredited nationally by the South African authorities such as the South African Qualifications Authority (SAQA). Leaders in these establishments always smoothen their students' consciences by assuring them of overseas (always USA) accreditations, not informing them that the South African education authority does not recognize foreign accreditation or foreign curriculums, unless an institution is in line with SAQA and is also internationally accredited by reputable authorities. This makes one understand why these preachers always transmit sermons which are downloaded from the internet, or from popular literature authored by some of their international counterparts. The fundamental fact is that since its inception, today's Pentecostalism does not start with the biblical text to formulate a theology. They instead 'work with their experiences that they have and assume that it can be regarded as biblical' (Menzies 1985:13). They are open to criticism for eisegesis that allows their experience to precede their biblical hermeneutics. 
They are also quick to "suspend the rationalistic thought process, when deemed necessary, and rely on a sense of spiritual "intuition", "imagination" and "consciousness" (Holm 1995:9).

The Neo-Pentecostals, with their classical Pentecostal sentiment, possess a strong primitivist and restorationist tendency towards the 'original apostolic church', therefore having all types of polity: Congregational, presbyterial, and even episcopal. In most cases, these polities are concocted to articulate structured or organized systems for the church government along the corporate lines. The pastor, who in most cases is a/the founder, is the chief operations officer. He leads as a monarch and surrounds himself with a team of faithful devotees. These are men and women who directly or indirectly pledge an allegiance or commitment to the 'servant of God' and must ensure that the vision of the pastor is carried out by all the followers. The corporate image of the church is always visible, accompanied by vision and mission statements, together with the core values. Church administration is delegated to the faithful devotees who are within the inner circle of the pastor. These corporate practices are inherited from the Shepherding movement's pyramid scheme of the gathered members (cells). Many Neo-Charismatic churches operate as a web of apostolic networks, as members connect to each other through cell systems. Each cell leader is regarded as a shepherd to the few followers allocated to them. Resane (2008:41) has captured the church government structure of the Neo-Pentecostal church founded on the five ministries, which carry out accountability, authority, and the direction of the church.

Regardless of this perceived polity, the apostolic network is crucial to many Neo-Charismatic churches. A network is explained by Cannistraci (1996:190) as autonomous churches or ministries voluntarily uniting to form an entity. Networks operate under some form of apostolic oversight, and members' relationships operate with a higher degree of interdependency. Networks always have a common vision, and from the hierarchical leadership, there is no dictatorship regarding methods, values, philosophies, and goals (Cannistraci 1996:190). The networks' strength is based on relationships and not dogma. There are no central controls in matters of finances, legal requirements, or disciplines. Apostolic networks exist for a mutual strengthening, capacity building, and the accomplishment of the apostolic ministry.

Wagner (1999:6) points out that structures are initiated for evangelistic and ministry effectiveness, although some leaders consider them 
as inefficient or ineffective. Neo-Pentecostals regard church polity or organograms as restrictive to the spiritual manifestations and prophetic revelations intended for the church. They regard traditional polity as a way of clipping the wings of creativity and squelching God's calling upon people's lives to fulfil their missio Dei in the world (Resane 2008:42). However, lately, especially with the Neo-Charismatics inclined towards the New Apostolic Reformation, there is a constant demand for the rigid authoritarian structures where the church leader, who is sometimes called an 'apostle' or a 'bishop', is the final authority in all ecclesiastical rhetorics such as doctrine, praxis, polity, and leadership development. One constantly hears the echo that '[t]he apostle watches over church doctrine' (Ekman 1995:78). In many cases, as a way of dominance, 'the (apostolic) covering concept is still viewed as being vital to the restoration of the church' (Moriarty 1992:78; original emphasis). Sadly, the fivefold ministry is applied by the modern Neo-Pentecostals to officially draw the focus away from Jesus' reasons and motives for these gifts. Jesus is the 'giver' of servant leaders, not the 'elevator' of people to office or position (Hayford, quoted in Green 2005:xii). People are abused when authority is used to subdue them to ungodly behaviors or practices that work against Christ's person and soteriological intentions. Kraft (1997:96) correctly points out that 'authority is misused whenever it exalts the person to whom the authority is given, rather than the Lord, the source and giver of authority'.

\section{Conclusion}

The Shepherding movement taught us various lessons, especially for theologians and church leaders: 'No one is immune to spiritual pride. We are all prone to that inner desire for power, control, and recognition' (Sherman 1990: 24). A responsible use of authority is of real concern in our society at large, more so in Neo-Pentecostal churches. Almost on a daily basis we hear of pastors, apostles, prophets, and bishops who blatantly misuse or abuse their authority.

The Shepherding movement started to decline in the mid-1980s. The scrutiny of authors such as Young (2019), Moore (2003), and Moriarty (1992) leads one to the demise of the movement: Prince ceased his identity with it in 1983. The movement's major publication, New Wine, lost huge revenue and ceased its publication in 1986. Towards the end of that decade (the 1980s), 
Baxter, Basham, and Mumford officially discharged their followers from their pyramid authority structure. Prince and Mumford specifically abandoned the movement and started to denounce the movement's teachings. In 1990, Mumford issued a formal repentance statement to the body of Christ (Wilhelm 2015).

That movement cautions today's church to pay attention to the theology of leadership, accountability, and liberative approaches to family life and women's roles in church leadership. The church of the $21^{\text {st }}$ century needs to acquire some lessons from the Shepherding movement, especially with reference to the theology of leadership, submission and inclusiveness, and the importance of theological education. Their leadership was made up of white middle-class males, imposing subjugation and coercion instead of a biblical submission to authority.

Their influence in the modern Neo-Pentecostal movement is observable through the emphasis on extra-biblical revelation, which has been promoted through personal prophecies and some falsified manifestations of the Spirit such as forcing the devotees into some strange practices. In the article it is pointed out that the Shepherding movement was not familiar with the latter practices, but they paved the way for it by emphasizing the extrabiblical revelation with the emphasis on charisma that revolves around the leadership. Precautionary measures to be taken are the apostolic exhortation that these teachers should be left alone. If their ministry is of divine origin, it will stand the test of time, but if it is of human origin, it will never survive (Ac 5:38-39).

\section{References}

Barker, J. 2001. Afterword. Journal of Ritual Studies 15, 2: 105-108.

Barret, D. 1982. World Christian Encyclopedia. New York: Oxford University Press.

Basham, D. 1974. Leadership: A biblical look. New Wine Magazine, March 1974: 14-17.

Basham, D. 1980. A covenant community. New Wine Magazine, February 1980: 30-33.

Basham, D. 1986. True and false prophets. Grand Rapids: Chosen Books. 
Cannistraci, D. 1996. Apostles and the emerging apostolic movement: A biblical look at apostleship and how God is using it to bless his church today. Ventura: Renew Books.

Durnbaugh, D. 1964. The believer's church. New York: Macmillan.

Ekman, U. 1995. The apostolic ministry: Can the church live without it? Uppsala: Kingsway Publications.

Green, M.D. (ed.) 2005. Understanding the fivefold ministry. Lake Mary: Charisma Media.

Gunda. M.R. \& F. Machingura 2013. The 'man of God': Understanding biblical influence on contemporary mega-church prophets in Zimbabwe. In Chitando, E., M. Gunda \& J. Kügler (eds.): Prophets, profits and the Bible in Zimbabwe: Festschrift for Aynos Masotcha Moyo. Bamberg: University of Bamberg Press.

Hayford, J.W. \& S.D. Moore 2006. The Charismatic century: The enduring impact of the Azusa Street revival. New York: Warner Faith.

Holm, R. 1995. A paradigmatic analysis of authority within Pentecostalism. $\mathrm{PhD}$ thesis, Faculty of Graduate Studies, Laval University, Quebec, USA.

Johnson, D. \& J. VanVonderen 1991. The subtle power of spiritual abuse: Recognizing and escaping spiritual manipulation and false spiritual authority within the church. Minneapolis: Bethany House Publishers.

Kraft, C.H. 1997. I give you authority. Grand Rapids: Baker Books.

MacTavish, R. 2014. Pentecostal profits: The prosperity gospel in the global south. M.A. Dissertation, Religious Studies, School of Graduate Studies, University of Lethbridge, Alberta, Canada.

Menzies, W. 1985. The methodology of Pentecostal theology: An essay on hermeneutics. In Elbert, P. (ed.): Essays on apostolic themes: Studies in honour of Howard M. Ervin. Peabody: Hendrickson.

Moore, S.D. 2003. The Shepherding movement: Controversy and Charismatic ecclesiology. New York: T. \& T. Clark.

Moriarty, M.G. 1992. The new Charismatics. Grand Rapids: Zondervan.

Mumford, B. 1973. Christ in session. Ft Lauderdale, Bob Mumford Ministries, 82-83.

Mumford, B. 1975a. Life changers newsletter. Holy Spirit Research Center, Oral Roberts University, Tulsa. November 1-8, 1975.

Mumford, B. 1975b. The vision of the local church. New Wine Magazine, July/August 1975: 4-8. 
Mumford, B. 1976. Disciple position paper. Unpublished paper. Private holding, 11.

Mzondi, A.M.M. 2017. Ubuntu Pentecostalism. Roodepoort: Anthony's Fast Print.

Prince, D. 1972. The apostle - God's master builder. New Wine Magazine, February 1972: 18-23.

Prince, D. 1973. God's man on the move. New Wine Magazine, March 1973: 11-15.

Quebedeaux, R. 1983. The new Charismatics II. San Francisco: Harper \& Row.

Resane, K.T. 2008. A critical analysis of the ecclesiology of the emerging apostolic churches with special reference to the notion of the fivefold ministry. PhD thesis, Department of Theology, Dogmatics and Christian Ethics, University of Pretoria, Pretoria.

Resane, K.T. \& J. Buitendag 2008. The temptation of realpolitik and vox populi in the ecclesiology of the emerging Apostolic churches with special reference to the fivefold ministry. HTS Theological Studies 64, 3: 1527-1551.

Sherman, D. 1990. Spiritual warfare for every Christian: How-to live-in victory and retake the land. Seattle: YWAM Publishing.

Simpson, C. 1972. Covering of the Lord. New Wine Magazine, October 1972: 24-27.

Wagner, C.P. 1999. Churchquake! Ventura: Regal.

Wilhelm, T., 2015, Is 9Marks the New Shepherding movement? Thou Art the Man. December 26, 2015. Available at: https://thouarttheman.org/ 2015/12/26/is-9marks-the-new-shepherding-movement/. (Accessed on November 30, 2019.)

Young, J. 2019. The Shepherding movement: A summary. November 30, 2019. Available at: https://jacobyoung84.medium.com/the-shepherding-movement-a-summary-5883c3d27e9f. (Accessed on March 25, 2021.)

Dr Kelebogile T. Resane Research Fellow, Department of Historical and Constructive Theology Faculty of Theology and Religion University of the Free State E-mail: resanekt@ufs.ac.za 